\title{
Geneza i znaczenie Kodeksu Prawa Prywatnego Kantonu Zurychu dla kodyfikacji prawa prywatnego w Szwajcarii na przykładzie prawa spadkowego
}

Kodeks Prawa Prywatnego Kantonu Zurychu (Privatrechtliches Gesetzbuch für den Kanton Zürich- $P G B)$ w literaturze poświęconej kodyfikacji prawa prywatnego Konfederacji Szwajcarskiej opisywany jest jako najdoskonalszy wzorzec dla Szwajcarskiego Kodeksu Cywilnego. ${ }^{1}$ W płaszczyźnie politycznej PGB było pierwszym znaczącym dziełem powstałym na podwalinach dopiero tworzącej się współczesnej państwowości Szwajcarii, wychodzącym ponad poziom trwającego od początku XIX w. sporu konserwatystów z liberałami. ${ }^{2} \mathrm{~W}$ płaszczyźnie prawo-

${ }^{1}$ P. Tuor, Das Schweizerische Zivilgesetzbuch, Zürich 1932 r., s. 3.

2 Tworzenie podwalin współczesnej państwowości Szwajcarii rozpoczęło się jeszcze w czasach napoleońskich. Pierwszą współczesną podstawą ustrojową była tzw. Konstytucja Mediacyjna z 19 lutego 1803 roku. Szwajcaria została podzielona na 19 Kantonów, gdzie każdy Kanton posiadał własną Konstytucję określającą jego szczególny ustrój i system ustawodawczy. Za: J. Dierauer, Geschichte der Szchweizerischen Eidgenossenschaft, Tom V cz. I, Gotha 1922, s. 183-188. Po upadku Napoleona Szwajcarzy stanęli przed wyzwaniem stworzenia nowego porządku konstytucyjnego. W kraju ścierały się dwie siły polityczne: zwolennicy starego porządku pod przewodnictwem berneńskiego patrycjatu, którzy dążyli do przywrócenia stanu prawno-ustrojowego sprzed 1798 roku i zwolennicy reform, którzy chcieli ochronić zdobycze rewolucji, a w szczególności do politycznego umocnienia Szwajcarii poprzez pogłębienie związku wszystkich Kantonów. Za: J. Dierauer, Geschichte der Szchweizerischen Eidgenossenschaft, Tom V cz. II, Gotha 1922, s.337. Po otrzymaniu wiadomości o powrocie Napoleona z Elby i w obliczu ponownej utraty suwerenności przedstawiciele wszystkich Kantonów zjednoczyli się uchwalając 9 sierpnia 1815 roku umowę związkową pomiędzy dwudziestoma dwoma Kantonami (Bundesvertrag zwischen den XXII Cantonen der Schweiz) gwarantującą niezawisłość konstytucji kantonalnych i nienaruszalności terytoriów poszczególnych Kantonów przy jednoczesnym zapewnieniu istnienia związku wszystkich terytoriów Szwajcarii. Pokój stronnictwa konserwatywnego i liberalnego był krótkotrwały. W latach 30. XIX wieku podejmowano próby rewizji umowy związkowej. Przyczyną dążenia do zmian było przeświadcze- 
dawczej PGB stało się trzecią siłą napędzającą wschodnie Kantony Szwajcarii ${ }^{3}$ do przeprowadzenia własnych prac kodyfikacyjnych, podobnie jak w zachodnich i centralnych Kantonach oddziaływały francuski Code Civil i austriacki $A B G B .{ }^{4}$ Kodeks Zurychu miał jednak pewną szczególną cechę, która wyróżnia go na tle pozostałych dziewiętnastowiecznych kodyfikacji. Był to pierwszy w Szwajcarii nowoczesny kodeks cywilny przesycony niemiecką tradycją i kulturą prawną, który jednocześnie stał na wysokim poziomie opracowania naukowego. PGB dało świadectwo żywotności prawa niemieckiego w Szwajcarii, ${ }^{5}$ a jego stabilne osadzenie w duchu narodu przełożyło się na wysoki poziom akceptacji społecznej zawartych w nim rozwiązań prawnych. Pozostaje pytanie, do jakiego stopnia można przypisać wpływ PGB na projekt i ostateczny kształt Szwajcarskiego Kodeksu Cywilnego (ZGB) ${ }^{6}$, a na ile należy traktować te kodeksy jako niezależne dzieła, choć stworzone na kanwie tych samych założeń początkowych, to znaczy stworzenia kodeksu, który w równym stopniu korzystałby ze zdobyczy nauki, jak i tradycji narodowych. ${ }^{7}$ Ewentualny wpływ PGB na ZGB najpełniej zobrazuje dział prawa spadkowego, który po pierwsze bezpośrednio ingeruje w osobistą sferę życia obywatela, w związku z czym dla swej skuteczności musi być osadzony w kulturze i tradycji narodowej, po drugie jest działem prawa, który w okresie poprzedzającym unifikację był najbardziej zróżnicowanym obszarem regulacyjnym w Szwajcarii. ${ }^{8}$

nie o anachronicznym charakterze Parlamentu Konfederacji Szwajcarskiej (Tagsatzung), ponieważ Kantony przestały uznawać kompetencje Parlamentu, forsując osiągnięcie celów lokalnych kosztem dobra całej Konfederacji. Za: J. Dierauer, Geschichte der Szchweizerischen Eidgenossenschaft, Tom V cz. II, Gotha 1922, s. 573. Kompromis udało się osiągnąć dopiero w 1848 wraz z uchwaleniem Konstytucji Konfederacji Szwajcarskiej. Zgodnie z art. 5 Konstytucji Konfederacja zapewniła Kantonom nienaruszalność terytorialną, suwerenność w granicach art. 3 Konstytucji, a zatem suwerenność w zakresie wykonywania wszystkich praw za wyjątkiem tych zarezerwowanych dla Konfederacji. Prawo skodyfikowania prawa cywilnego pozostawało nadal w gestii Kantonów.

${ }_{3}^{3}$ P. Caroni, Privatrecht. Eine sozialhistorische Einfuihrung, Basel und Frankfurt am Main, 1988, s. 36.

${ }^{4}$ A. Bauhofer, Entstehung und Bedeutung des zürcherischen privatrechtlichen Gesetzbuches von 1853-1855, osobny wydruk z ,Zeitschrift für Schweizerisches Recht Neue Folge“, Tom 46 z. 1, Basel 1927, s. 2.

5 Ibidem, s. 64.

${ }^{6}$ G. Kocher, Privatrechtsentwicklung und Rechtswissenschaft in Österreich, Wien, Köln, Weimar, Böhlau 1997, s. 68.

${ }^{7}$ E. Huber, Betrachtungen über die Vereinheitlichung des Schweizerischen Erbrechts, Basel 1895, s. 3.

${ }^{8}$ E. Huber, Schweizerisches Zivilgesetzbuch, Erläuterungen zum Vorentwurf des eidgenössischen Justiz- und Polizeidepartaments, Zweite, durch Verweisungen auf das Zivilgesetzbuch und etliche Beilagen ergänzte Ausgabe (1914), Erster Band, Dritter Teil: Das Erbrecht,[w:] M. Reber, Ch. Hurni (red.), Berner Kommentar, Kommentar zum schweizerischen Zivilgesetzbuch, Band II, Bern 2007, s. 303 (s. 319 Erläuterungen ...). 


\section{STAN PRAWNY PRZED UCHWALENIEM PGB}

Prowadzenie prac kodyfikacyjnych w Kantonie Zurychu wiązało się z koniecznością przełamania istniejącego na początku XIX wieku partykularyzmu prawnego. W tym okresie obowiązywały tam nadal ustawy wybiórczo regulujące poszczególne działy prawa, liczne prawa miejskie, prawa dworskie i statuty, które powstały na przestrzeni XV-XVIII w. ${ }^{9}$ Ustawą regulującą prawo spadkowe było przede wszystkim miejskie prawo spadkowe miasta Zurychu z 1716 roku (Erb-Recht der Statt Zürich, anno 1716 ${ }^{10}$ i lokalne prawa zachowane na terenach wiejskich, jak np. prawo spadkowe hrabstwa Kyburg z 1578 czy obszaru Regensberg z 1538 roku. ${ }^{11}$

Erb-Recht była ustawą najczęściej stosowaną w procesie spadkobrania. Hołdowało zasadzie silnego ograniczenia praw spadkowych kobiet i daleko posuniętej kazuistyki rozwiązań prawnych. Na przykład mocą § XII cz. II Erb-Recht der Staat Zürich anno $1716 r$ synowie mieli pierwszeństwo dziedziczenia nieruchomości po ojcu, przy czym dom, w którym mieszkał ojciec przypadał w udziale najmłodszemu synowi. Wszyscy synowie dziedziczyli przedmioty osobiste ojca, bez konieczności uzupełniania pozostałej masy spadkowej o wartość dziedziczonych przedmiotów. Chodziło tu o takie przedmioty jak książki, stroje i broń. Pieczęć rodowa była dziedziczona przez tego syna, który nosił imię chrzestne po ojcu. Jeśli pieczęć była częścią majątku, która przedstawiała znaczącą wartość w stosunku do pozostałej masy spadkowej, syn ją dziedziczący musiał uzupełnić spadek swoich braci o „słuszne odszkodowanie”. Pozostała masa spadkowa była dziedziczona pomiędzy synów i córki w stosunku 5:4.

Majątek matki dziedziczony był analogicznie do majątku po ojcu, z tą różnicą, że przedmioty użytku osobistego matki, jak ubrania, klejnoty i książki, przypadały w spadku córkom. Wartość przedmiotów użytku osobistego matki nie mogła przekraczać połowy wysokości spadku należnego synom. ${ }^{12}$

Niekorzystna sytuacja spadkowa kobiet wyraźnie rysowała się także w sytuacji, w której rodzice dziedziczyli po sobie wzajemnie lub gdy dziedziczyli majątek dzieci. W braku żyjących zstępnych, małżonkowie dziedziczyli po sobie

9 A. Bauhofer, op.cit., s. 3.

${ }^{10}$ Kodeks miał trójdzielną budowę. Część pierwsza kodeksu dotyczyła dziedziczenia testamentowego (von Testamenten). Część druga dotyczyła dziedziczenia ustawowego (Von denen so ohne Testament erben) i część trzecia o kodycylu, legacie, fideikomisie i pozostałych przepisach prawa spadkowego (von Codicillis, Legatis, Fideicommissis und übrigen zum Erbrecht gehörigen Erläuterungsartikeln).

${ }_{11}$ J. C. Bluntschli, Staats- und Rechtgeschichte der Stadt und Landschaft Zürich, T. I, Zürich 1838, s. 295.

${ }^{12}$ Erb-Recht der Staat Zürich anno 1716, cz. II § XII. 
wzajemnie, choć uprawnienia wdowy ograniczały się do jej przedmiotów użytku osobistego i podarków otrzymanych przez nią od męża za jego życia. Oprócz tego żona była uprawniona do piątej części majątku zgromadzonego przez małżonków w trakcie trwania małżeństwa, do jednej piątej przedmiotów stanowiących wyposażenie domu i do jednej szóstej majątku odziedziczonego przez męża za jego życia. ${ }^{13} \mathrm{~W}$ przypadku pozostawienia przez zmarłego żyjących zstępnych, uprawnienia wdowy do majątku były jeszcze bardziej ograniczone. ${ }^{14}$

W sytuacji, w której rodzice byli spadkobiercami dzieci, a zatem jeśli te nie pozostawiły po sobie żyjących zstępnych, ich majątek był dziedziczony przez ojca. ${ }^{15}$ Matka mogła dziedziczyć jedynie wtedy, gdy spadkodawca nie pozostawił zstępnych, rodzeństwa ani ojca. Masa spadkowa przypadająca matce obejmowała wówczas połowę ubrań, przedmiotów użytku domowego, damskiej biżuterii i książek dziecka, a także jedną piątą pozostałego majątku. ${ }^{16}$

Mimo że Erb-Recht systemowo stało niżej aniżeli testament, dziedziczenie ustawowe było najczęściej wybieraną formą przekazania dziedzicom masy spadkowej. Poniekąd thumaczy to fakt niskiego poziomu opracowania pierwszej części Prawa Spadkowego Zurychu, tj. dziedziczenia testamentowego. Podstawowym zarzutem formułowanym $\mathrm{w}$ stosunku do instytucji testamentu uregulowanego w Erb-Recht był w zasadzie brak różnicy pomiędzy nim a kodycylem. ${ }^{17}$ Zgodnie $\mathrm{z}$ art. 1 części pierwszej Erb-Recht, testament stanowił całkowite, wyraźne, jasne i niewymuszone wyrażenie ostatniej woli. Kodycyl z kolei to oświadczenie złożone na wypadek śmierci bez wskazania konkretnych spadkobierców. ${ }^{18}$

J.C. Bluntschli, po przeprowadzeniu badań prawno-porównawczych będących punktem wyjściowym dla późniejszych prac kodyfikacyjnych, winą za niefrasobliwe zredagowanie przepisów obarczył uczonych w prawie rzymskim, którzy uczyli się o rzymskich instytucjach bez prawidłowego ich zrozumienia, a następnie próbowali przeszczepić je na grunt szwajcarski. Bluntschli dowodził, że rozróżnienie pomiędzy kodycylem a testamentem w prawie spadkowym miasta Zurychu miałoby sens, gdyby testament polegał na wyrażeniu ostatniej woli ze wskazaniem spadkobierców. Ustawa jednak milczała w tym zakresie, sugerując jedynie, że powołanie konkretnych spadkobierców było możliwe, ale nie wymagane. Kodycyl z kolei wykluczał możliwość imiennego wskazania osób upoważnionych do spadku. Jako że zarówno kodycyl, jak i testament musiały być sporządzone w formie aktu notarialnego, a wymogi dotyczące testamentu mogły być

13 Ibidem, $\S$ I zd. 2.

14 Ibidem, § I zd. 4 i nast.

15 Ibidem, § VII zd. 1.

16 Ibidem, § VII zd. 3.

17 A. Bauhoffer, op. cit. s. 4; J.C. Bluntschli, Staats- und Rechtgeschichte ..., s. 318-319.

18 Erb-Recht der Staat Zürich anno 1716, cz. III $§ 1$. 
łatwo spełnione, w praktyce niezwykle rzadko zdarzało się, że kodycyl nie był jednocześnie testamentem. ${ }^{19}$ Osobne uregulowanie tych instytucji w Erb-Recht z 1716 roku było zatem całkowicie bezzasadne i zbędne.

Bluntschli negując rzymskie korzenie testamentu z Erb-Recht z 1716 porównał go z wcześniej funkcjonującą na terenie Zurychu i pozostałych Kantonów Szwajcarii instytucją Gemächde. Była to forma oświadczenia woli złożonego na wypadek śmierci, która mogła być swobodnie korygowana przez sędziego w postępowaniu spadkowym. Gemächde o wiele częściej zawierała wskazówki co do sposobu postępowania z masą spadkową bez wskazania konkretnych uprawnionych, aniżeli z ich wyraźnym powołaniem. Zgodnie $\mathrm{z}$ argumentacją Bluntschliego $\mathrm{z}$ historycznego punktu widzenia testament $\mathrm{z}$ Erb-Recht $\mathrm{z} 1716$ roku powinien być identyfikowany z rdzennie niemiecką instytucją Gemächde, a nie z testamentem pochodzącym z prawa rzymskiego.

Zdaniem Bluntschliego, przewaga niemieckiej kultury prawnej w kształtowaniu instytucji testamentu na terenie miasta Zurychu wyrażała się także w zachowaniu w niezmienionej postaci starej germańskiej zasady, że spadki są regulowane istniejącymi stosunkami rodzinnymi ${ }^{20}$ Testator wprawdzie dysponował pewną swobodą w zakresie rozporządzania swoim majątkiem na wypadek śmierci, jednak w porównaniu z innymi europejskimi regulacjami była to swoboda najbar-

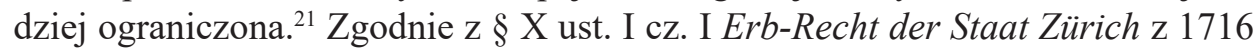
roku, spadkodawca był zobowiązany do pozostawienia swoim dzieciom i wnukom całości swego majątku ${ }^{22}$. Ponadto majątek odziedziczony wraz z czwartą częścią majątku zdobytego należał się rodzeństwu. Także dla dzieci rodzeństwa przewidziany był obowiązkowy udział w masie spadkowej w wysokości trzeciej części majątku odziedziczonego. ${ }^{23}$

Stanowisko Bluntschliego co do przesycenia instytucji prawa spadkowego tradycją narodową wynikała nie tyle $\mathrm{z}$ wiedzy popartej doświadczeniem w sferze badań nad pochodzeniem poszczególnych regulacji, ale było ono efektem przekonania o słuszności założeń historycznej szkoły prawa. Należał on bowiem do radykalnie germanizującego odłamu tej szkoły, która głosząc potrzebę wskrzeszenia prawa rdzennie niemieckiego i wszechstronnego jego opracowania w doktrynie, jednocześnie zwalczała teorię recepcji prawa rzymskiego in complexu. ${ }^{24} \mathrm{~W}$ swoim

19 J. C. Bluntschli, Staats- und Rechtgeschichte ..., s. 319.

${ }^{20}$ P. Guggenbühl, Die Entstehung des zürcherischen privatrechtlichen Gesetzbuches, Meilen 1924, s.117.

${ }^{21}$ Ibidem, s. 118.

22 „Es sollen die Elteren und Gross- Elteren ihr ganzes Haab und Gut [...] ihren Kinderen und Kindskinderen zwahren zu überlassen pflichtig sehn.”

${ }^{23}$ P. Guggenbühl, op.cit. s. 118.

${ }^{24} \mathrm{~K}$. Sójka-Zielińska, W sprawie oceny romanistycznego i germanistycznego kierunku szkoby historycznej w niemieckiej nauce prawa I połowy XIX w., „Czasopismo Prawno-Historyczne” Tom XI, z. 2 1959, s. 132. 
dziele pt. Staats und Rechtsgeschichte der Staat und Landschaft Zürich ${ }^{25}$ dowodził, że romanistyczny element instytucji prawnych Zurychu ma zdecydowanie mniejsze znaczenie aniżeli element germański i że tak naprawdę prawo zuryskie jest bardziej niemieckie aniżeli prawo obowiązujące w samych Niemczech. ${ }^{26}$

Erb-Recht der Statt Zürich było pierwszą, choć nie do końca udaną, próbą uporządkowania kwestii spadkobrania na terenie miasta Zurychu. Ustawie brakowało naukowego opracowania, jako że nie ustrzegła się ona przed kazuistycznym ujęciem większości instytucji. Język ustawy, przywołujący na myśl tytułami poszczególnych przepisów redakcję poradnika ${ }^{27}$, był zagmatwany i niejasny, a niepełne opracowanie poszczególnych materii ${ }^{28}$ wskazywało na potrzebę ponownej, całościowej redakcji przepisów prawa spadkowego. Pomimo niewątpliwych mankamentów, ustawa była dla twórcy Kodeksu Prawa Prywatnego Kantonu Zurychu cennym źródłem poglądowym, zarysowującym zuryską kulturę dziedziczenia opartą na zasadach ograniczonej swobody testowania, ochrony interesów ekonomicznych osób połączonych więzami pokrewieństwa i uprzywilejowania dziedziczenia w linii męskiej.

\section{KODYFIKACJA PRAWA CYWILNEGO KANTONU ZURYCHU}

Właściwy moment dla kodyfikacji prawa cywilnego Kantonu Zurychu nadszedł w latach trzydziestych XIX wieku. Związek Kantonów Szwajcarii przeżywał kryzys, którego efektem było skupienie się poszczególnych terytoriów na potrzebach lokalnych. Owocem tego kryzysu dla Kantonu Zurychu było uchwalenie 10 marca 1831 roku Konstytucji kantonalnej, której art. 21 przewidywał pełną rewizję wszystkich istniejących ustaw. ${ }^{29} \mathrm{Już}$ w trakcie prac nad samą Konstytucją większość petycji kierowanych do komisji konstytucyjnej dotyczyło wniosków o zmianę poszczególnych gałęzi prawa, ${ }^{30} \mathrm{~W}$ tym wniosków o ujednolicenie prawa spadkowego i zredagowanie kodeksu cywilnego. ${ }^{31}$

25 J.C. Bluntschli, Staats- und Rechtsgeschichte der Stadt und Landschaft Zürich, Zürich 18381839.

${ }^{26}$ Ibidem, s. VII.

27 Vide: cz. I $§ 4$ „Które osoby mogą testować?” (Welche Personen Testieren mögen), cz. II $§ 9$ „Jak unieważnić testament?"(Wie die Testament wieder aufgehebt werden).

${ }^{28}$ E.Huber, System und Geschichte des schweizerischen Privatrechts, t. IV, Basel 1893, s. 128.

29 Art. 21 Staatsverfassung für den eidgenössischen Stand Zürich vom 10. März 1831, tekst dostępny pod adresem: http://www.verfassungen.de/ch/zuerich/verf31-i.htm [dostęp: 25.11.2013].

${ }^{30}$ W. Wettstein, Die Regeneration des Kantons Zürich. Die liberale Umwälzung der dreissiger Jahre 1830-1839, Erster Teil, Zürich 1906, s. 41.

${ }^{31}$ H. Nabholz, Die Eingaben des zürcherischen Volkes zur Verfassungsrevision des Jahres 1830, Neujahrsblatt der Stadtbibliothek Zürich, t. 267, Zürich 1911, s. 29. 
W 1831 Wielka Rada powołała komisję do spraw rewizji ustaw, której zadaniem było, między innymi, skodyfikowanie prawa cywilnego. Na czele komisji stanął Friedrich Ludwig Keller, wówczas przewodniczący sądu drugiej instancji w Zurychu. Z niejasnych przyczyn ${ }^{32}$ Keller nie wykonał powierzonego mu zadania i w 1840 prace nad kodyfikacją prawa cywilnego przejął Johann Caspar Bluntschli. ${ }^{33}$ Efektem jego starań było wejście w życie 31 marca 1854 r. części kodeksu obejmującego prawo osobowe i rodzinne, prawa rzeczowego 1 lipca 1854 r., prawa zobowiązań 1 lipca 1855 r. i wreszcie prawa spadkowego 31 marca 1856 roku. ${ }^{34}$

Opracowanie prawa spadkowego stanowiło najpiękniejszą, a zarazem najtrudniejszą część pracy Bluntschliego. Jest to dział prawa najsilniej ingerujący w prywatną sferę życia, dlatego narzucanie przepisów, które nie byłyby prawidłowo osadzone w narodowej kulturze i tradycji, nie miałyby prawa bytu. Ponadto autor kodyfikacji podkreślał, że podczas gdy pozostałe działy prawa prywatnego rozwijały się w miarę równomiernie i zgodnie z duchem czasu, prawo spadkowe było regulowane mozaiką przepisów rozmaitej proweniencji. ${ }^{35}$

Pomimo oczywistych trudności zdecydowano o nowym opracowaniu prawa spadkowego z kilku względów. Po pierwsze obowiązujące na terenie Kantonu Zurychu regulacje dotyczące prawa spadkowego były fragmentaryczne, a ich zakres obowiązywania ograniczał się do historycznych terytoriów władztw, które w czasie kodyfikacji już nie istniały (np. Kyburg, Grünningen, Wülfingen). ${ }^{36}$ Po drugie, zmianie uległy stosunki rodzinne, które zostały na nowo uregulowane wraz z wejściem w życie pierwszej części kodeksu cywilnego i nie istniały żadne logiczne przesłanki przemawiające za utrzymaniem niejednorodnych i przestarzałych przepisów dotyczących spadkobrania. ${ }^{37}$ Po trzecie wreszcie, zasady prawa spadkowego wypracowane na przestrzeni dziejów pozostawały w głębokiej dysharmonii w stosunku do wówczas wyznawanego systemu wartości. ${ }^{38}$

32 Szerzej: M. Lewandowicz, Friedrich Ludwig Keller i nowe teorie w Wymiarze Sprawiedliwości Zurichu (Die Neuen Theorien in der Zürcherischen Rechtspflege), „Studia Historyczne”, z. 1/2015, s. 49-50.

${ }^{33}$ E.F.I. Müller-Büchi, Friedrich von Wyss und das Zürcher Privatrechtliche Gesetzbuch, ,, Zeitschrift für Schweizerisches Recht”, Neue Folge, t. 84, Basel 1965, s. 327.

${ }^{34}$ A. Bauhoffer, op. cit. s. 23-24.

${ }^{35}$ Wyjaśnienie do § 1893 Privatrechtliches Gesetzbuch für den Kanton Zürich. Mit den Erläuterungen von Dr. Bluntschli Redaktor des Gesetzes, IV Band Erbrecht, Zürich 1856, pkt 1 a, s. 1.

${ }^{36}$ Ibidem, s. 2.

37 Wyjaśnienie do § 1893, Privatrechtliches Gesetzbuch für den Kanton Zürich..., op.cit. pkt 1 c, s. $2-3$.

${ }^{38}$ Ibidem, pkt 2, s. 3. 


\section{PRAWO SPADKOWE W ZURYSKIM KODEKSIE PRAWA PRYWATNEGO 1853-55}

\section{DZIEDZICZENIE USTAWOWE}

Stanowiące piątą księgę kodeksu prawa prywatnego kantonu Zurychu prawo spadkowe jest udanym efektem połączenia nauki z tradycją. Widać to już na przykładzie przyjętej systematyki, gdzie, w odróżnieniu do prawa spadkowego z 1716, przepisy piątej księgi PGB otwierają przepisy dotyczące dziedziczenia beztestamentowego, które w Zurychu było regułą. ${ }^{39} \mathrm{~W}$ swoim komentarzu J.C. Bluntschli wyjaśnia, że należało odrzucić tradycje prawa rzymskiego, które w pierwszej kolejności odwoływały się do woli spadkodawcy i zwrócić się ku podstawowym poglądom germańskiego kręgu kulturowego, zgodnie z którymi naturalnym porządkiem rzeczy jest ochrona związków i wartości rodzinnych. ${ }^{40}$

Pierwsza grupa dziedziczenia (parentela) obejmowała zstępnych spadkodawcy. W grupie tej obowiązywało nieograniczone prawo wstąpienia, polegające na tym, że w miejsce zmarłego zstępnego spadkodawcy wstępowały jego dzieci (wnuki spadkodawcy), które dziedziczyły w częściach równych udział, jaki przypadałby ich zmarłemu rodzicowi. ${ }^{41}$

Pomimo dążenia do jak najdalej idącego uwspółcześnienia przepisów prawa spadkowego, postanowiono utrzymać uprzywilejowanie synów w zakresie części spadku obejmującej nieruchomości po ojcu. Kwestia ta była przedmiotem zagorzałych dyskusji w Wielkiej Radzie i stanowiła jedno z większych wyzwań w zakresie ujednolicenia prawa spadkowego. U podstaw tych trudności leżało poważne zróżnicowanie sytuacji spadkowej synów i córek na obszarze Kantonu. W Winterthur, Rheinau i Kaiserstuhl, do czasu wejścia w życie PGB istniało pełne równouprawnienie. Erb-Recht z 1716 roku przewidywał podział majątku ojca w stosunku 5:4 z przewagą dla synów. W każdym wypadku synowie mieli prawo do przejęcia nieruchomości po ojcu przy założeniu obniżonej wartości tego majątku. ${ }^{42} \mathrm{Na}$ pozostałym terenie, w szczególności na terenach wiejskich, podział majątku pomiędzy synów i córki przypadał w części 2:1, a zatem synowie obejmowali dwukrotnie większą część majątku po zmarłym. ${ }^{43}$

39 Th. Weibel, Erbrecht und Familie. Fortbildung und Aufzeichnung des Erbrechts in der Stadt Zürich - vom Richterbrief zum Stadterbrecht von 1716, Zürich 1988, s. 243-244.

${ }^{40}$ Wyjaśnienie do $\S 1893$, Privatrechtliches Gesetzbuch für den Kanton Zürich. Mit den Erläuterungen von Dr. Bluntschli Redaktor des Gesetzes, IV Band Erbrecht, Zürich 1856, pkt 3, s. 4.

${ }^{41} \S 1894$ w zw. z $\$ 1905-\S 1907$ PGB.

42 P. Guggenbühl, op.cit, s. 116.

43 Wyjaśnienie do $\S 1895$, Privatrechtliches Gesetzbuch für den Kanton Zürich. Mit den Erläuterungen von Dr. Bluntschli Redaktor des Gesetzes, IV Band Erbrecht, Zürich 1856, pkt 1, s. 6. 
W wyjaśnieniu do $§ 1895$ PGB J.C. Bluntschli dowodził, że treść przyjętej regulacji, zakładającej uprzywilejowanie synów wobec córek w stosunku 5:4, stanowiła doskonały kompromis założeń prawa rzymskiego (równouprawnienia) z tradycją germańską (uprzywilejowanie płci męskiej, między innymi w zakresie spadkobrania). Jak argumentował twórca PGB, nie należy podważać równości synów i córek jako dzieci spadkodawcy, gdyż są one tak samo kochane i poważane przez rodziców. Jednak w rzeczywistości dzieci różnią się między sobą, a wyraża się to w wyższości płci męskiej w zakresie fizycznych i intelektualnych talentów. To bowiem mężczyzna-syn jest predestynowany do bycia głową rodziny (podczas gdy córka będzie jedynie jej członkiem), a także to na synu spoczywa ciężar zachowania ciągłości rodu. Na wzór rzymski zatem zniwelowano rażącą różnicę 2:1 w zakresie prawa córek do majątku po zmarłym rodzicu pozostając jednak przy „naturalnym” porządku rzeczy nieznacznego uprzywilejowania synów wobec córek w stosunku 5:4 (§ 1902 PGB). ${ }^{44} \mathrm{~W}$ odniesieniu do spadku po matce dzieci zostały równouprawnione, z wyjątkiem prawa do nieruchomości ( 1904 PGB), zaś mocą §1898 PGB zniesiono uprzywilejowanie niektórych synów w zakresie prawa do spadku po ojcu (jak miało to np. miejsce w prawie spadkowym z 1716 r.).

W PGB ciekawie rozwiązano kwestię spadkobrania przez dzieci adopcyjne. Zgodnie z dyspozycją § 1915 PGB w odniesieniu do majątku rodziców adopcyjnych, dzieci przysposobione miały równe prawa z dziećmi biologicznymi. Treść przepisu stanowiła systemową kontynuację treści § 246 PGB, zgodnie z którym dzieci adoptowane wchodziły w ogół praw i obowiązków dzieci biologicznych. Konkurencja spadkobrania pomiędzy dziećmi biologicznymi i adopcyjnymi następowała niezwykle rzadko, jako że adoptować mogły jedynie te małżeństwa, które nie posiadały dzieci biologicznych. ${ }^{45}$

Dzieci przysposobione nie traciły prawa do majątku po rodzicach biologicznych, z tym zastrzeżeniem, że w przypadku, gdy rodzice biologiczni posiadali obok dzieci oddanych do adopcji inne dzieci, które przy nich pozostały, dzieci oddane do adopcji nie mogły rościć sobie praw do przedmiotów majątku osobistego po zmarłym, a wartość odziedziczonego przez nie majątku nie mogła przekraczać połowy wartości majątku odziedziczonego przez dzieci nie oddane do adopcji. Jeśli jednak rodzice biologiczni nie posiadali innych dzieci, wówczas dzieci oddane do adopcji korzystały w pełnego prawa dziedziczenia. ${ }^{46}$

${ }^{44}$ Wyjaśnienie do $§ 1895$, Privatrechtliches Gesetzbuch für den Kanton Zürich. Mit den Erläuterungen von Dr. Bluntschli Redaktor des Gesetzes, IV Band Erbrecht, Zürich 1856, pkt 1, s. 6-9.

${ }^{45}$ Wyjaśnienie do $\S 1915$, Privatrechtliches Gesetzbuch für den Kanton Zürich. Mit den Erläuterungen von Dr. Bluntschli Redaktor des Gesetzes, IV Band Erbrecht, Zürich 1856, s. 30.

$46 \S 1915$ PGB. 
Najistotniejszą zmianą dla zuryskiego prawa spadkowego było dopuszczenie do spadkobrania krewnych matki na równi z krewnymi ojca ${ }^{47}$ i częściowe zrównanie praw rodziców w zakresie spadkobrania po dzieciach. §1917 PGB stanowił, że w przypadku gdy spadkodawca nie pozostawił po sobie żyjących zstępnych, wówczas jego majątek przypadał rodzicom (a nie, jak było do tej pory, ojcu). ${ }^{48} \mathrm{Od}$ tego przepisu istniały jednak liczne wyjątki.

Do czasu uchwalenia PGB w przeważającej części Kantonu obowiązywało prawo spadkowe całkowicie wykluczające lub częściowo ograniczające prawa matki i krewnych po kądzieli do spadkobrania. Komisja obradująca nad zmianą prawa spadkowego przedstawiała liczne propozycje dotyczące zmiany obowiązującego stanu prawnego. Pierwszy projekt Bluntschliego zakładał ustanowienie okresu przejściowego, w trakcie którego matka i jej krewni byliby dopuszczeni do spadkobrania, jednak ich udział w spadku konkurowałby z udziałem krewnych ojca w ten sposób, że krewni po kądzieli dziedziczyli przed rodziną ojca spokrewnioną ze spadkodawcą $\mathrm{w}$ dalszym stopniu niż spadkobiercy ze strony matki. ${ }^{49}$ Jeśli zatem w chwili śmierci spadkodawcy żyliby krewni zarówno ze strony ojca, jak i matki, w równym stopniu spokrewnieni ze spadkodawcą, wówczas krewni ojca wykluczyliby krewnych po kądzieli.

Z uwagi na przyjęte przez Wielką Radę stanowisko o równouprawnieniu spadkobierców ze strony ojca i matki, J.C. Bluntschli opracował drugi projekt, który po krótkich obradach zatwierdzono. W jego uzasadnieniu czytamy, że negowanie prawa matki do spadku po dziecku jest barbarzyństwem, jako że to ona urodziła i wychowała dziecko, a w przypadku jej śmierci dzieci odziedziczą pozostawiony przez nią majątek. $Z$ tego względu wykluczenie $\mathrm{z}$ dziedziczenia krewnych matki nie znajduje dłużej uzasadnienia. ${ }^{50}$

Zrównanie w prawach krewnych ze strony ojca i matki do dziedziczenia nie oznaczało zniesienia różnic w spadkobraniu ze względu na płeć i pozycję w rodzinie. Utrzymano bowiem przywilej ojca wobec określonego majątku syna (analogicznie

${ }^{47}$ P. Guggenbühl, op. cit., s.114.

${ }^{48}$ „Sind keine ehelichen Nachkommen des Erblassers vorhanden, wohl aber seine beiden ehelichen Eltern noch am Leben, so fällt seine Verlassenschaft diesen zu".

49 Wyjaśnienie do § 1917, Privatrechtliches Gesetzbuch für den Kanton Zürich. Mit den Erläuterungen von Dr. Bluntschli Redaktor des Gesetzes, IV Band Erbrecht, Zürich 1856, s. 32; §537 pierwszego projektu prawa spadkowego: „Das Erbrecht der Mutter und der ehelichen Nachkommenschaft der Mutter steht jederzeit dem Erbrecht des Vaters und der ehelichen Nachkommenschaft des Vaters um je ein Glied nach in der Weise, dass wenn Vater- und Muttermagen auf der gleichen Linie stehen, diese von jenen ausgeschlossen werden, wenn die Muttermagen wenigstensein Glied näher stehen als die Vatermagen, beiderlei Varwandte miteinander konkurrieren ", [w:] P. Guggenbühl, op. cit. s.114.

${ }^{50}$ Wyjaśnienie do $\S 1917$, Privatrechtliches Gesetzbuch für den Kanton Zürich. Mit den Erläuterungen von Dr. Bluntschli Redaktor des Gesetzes, IV Band Erbrecht, Zürich 1856, s. 33. 
jak synowie mieli pierwszeństwo w stosunku do określonego majątku ojca) i przywilej matki w stosunku do określonego majątku córki. ${ }^{51}$ Wyjątkiem było dziedziczenie przez rodzeństwo, gdzie zarówno siostry, jak i bracia mieli równy udział w spadku. ${ }^{52}$

Dziedziczenie ustawowe w kodeksie Zurychu hołdowało tradycji ochrony więzów pokrewieństwa, kreując sytuację wdowy nadal niekorzystnie, choć i tak lepiej, niż w prawach wcześniej obowiązujących. ${ }^{53}$ Po śmierci męża, żona miała prawo żądać od spadkobierców męża wydania jej z masy spadkowej posagu. W razie gdyby natychmiastowe wydanie napotykało znaczące trudności, sąd miał wyznaczyć odpowiedni termin na jego wydanie. ${ }^{54}$ Początkowo dyskutowano nad możliwością rozłożenia wypłaty posagu na raty, przy czym wypłata pierwszej raty miała nastąpić nie później niż po roku od otwarcia spadku. W obawie jednak przed nadużywaniem uprawnień przez spadkobierców męża postanowiono poddać kwestie terminów ocenie sądu. W praktyce bowiem częstokroć posag żony stanowił część kapitału zakładowego przedsiębiorstwa męża i to sąd był w stanie ocenić, kiedy wypłata należnej wdowie kwoty byłaby możliwa tak, aby zabezpieczyć jej interesy bez narażania na szwank bytu przedsiębiorstwa. ${ }^{55}$

Jeśli mąż pozostawił po sobie prawowitych zstępnych (eheliche Nachkommen), żonie przypadała na własność połowa przedmiotów domowego użytku (Hausrath) i, tak długo jak pozostawała wdową, prawo użytkowania jednej czwartej części pozostałego czystego majątku po mężu (z masy spadkowej odliczano uprzednio uprzywilejowany udział synów w spadku - p. § 1895 PGB). Ponadto, jeśli po śmierci męża żona decydowała się na przejęcie na własny koszt opieki i wychowania nieletnich dzieci, przysługiwało jej prawo korzystania z udziału spadkowego tych dzieci. ${ }^{56}$

W przypadku, gdy mąż nie pozostawił po sobie żyjących zstępnych, żona dziedziczyła na własność wszystkie przedmioty domowego użytku i, wedle własnego wyboru, jedną szóstą pozostałego czystego majątku męża lub, tak długo jak pozostawała wdową, użytkowanie połowy pozostałego majątku męża. ${ }^{57}$

\section{DZIEDZICZENIE TESTAMENTOWE}

Opracowując materię prawa spadkowego Bluntschli dokonał przełomu w regulacji testamentu. W zuryskiej tradycji dziedziczenie testamentowe było wyjąt-

$51 \S \S 1918-1919$ PGB.

$52 \S 1925$ PGB.

53 A. Bauhoffer, op. cit., s. 50.

${ }^{54} \S 1945$ PGB.

55 Wyjaśnienie do § 1945, Privatrechtliches Gesetzbuch für den Kanton Zürich. Mit den Erläuterungen von Dr. Bluntschli Redaktor des Gesetzes, IV Band Erbrecht, Zürich 1856, s. 57-58.

$56 \S 1948$ PGB.

$57 \S 1950$ PGB. 
kiem od zasady dziedziczenia ustawowego, a swoboda testowania była ograniczona do poziomu fikcji. Jak zauważył w swoich rozważaniach J.C. Bluntschli, w czasach kiedy pracowano nad PGB związki rodzinne nie były już tak silne i trwale uporządkowane jak miało to miejsce przed wiekami. ${ }^{58}$ Zmianie uległy nie tylko związki rodzinne, ale także społeczne. Życie nastawione było na rozwój indywidualny jednostki, która miała szerszą możliwość działania, w szczególności w odniesieniu do własnego majątku. Skoro wówczas współczesne życie zapewniało jednostkom coraz szerszą swobodę działania, nie było przekonujących argumentów przemawiających za utrzymaniem głęboko ingerujących ograniczeń w odniesieniu do swobody testowania. Choć reguła dotycząca kolejności dziedziczenia w rodzinie nadal zasługiwała na uwagę, to należało stworzyć warunki do swobody podejmowania decyzji o losach majątku indywidualnego po śmierci spadkodawcy. Tam, gdzie zdaniem spadkodawcy ustawa w sposób niewystarczający regulowała losy masy spadkowej, testator mógł je zgodnie ze swoją wolą ukształtować. ${ }^{59}$

Zakres swobody testatora co do rozporządzania własnym majątkiem na wypadek śmierci, choć został rozszerzony w stosunku do wcześniej obowiązujących regulacji (np. wobec norm prawa spadkowego z 1716 r.), nadal zawierał znaczące restrykcje. Jeśli spadkodawca pozostawił po sobie zstępnych, wówczas testator miał prawo do swobodnego rozporządzenia 1/5 swojego majątku w tym sensie, że wszystkim dzieciom łącznie należało się obowiązkowe 4/5 majątku spadkodawcy, zaś wybranemu dziecku lub dzieciom testator miał prawo zwiększyć udział w spadku łącznie o piątą część masy spadkowej. W przypadku, gdy testator miał zamiar pozostawić część swego majątku osobie trzeciej, obowiązkowy udział dzieci wynosił 9/10, przy swobodzie testatora w odniesieniu do dziesiątej części swego majątku. ${ }^{60}$ Udział procentowy w spadku dzieci przysposobionych ulegał obniżeniu do połowy udziału dzieci biologicznych, jednak dzieci adopcyjne miały nadal prawo dziedziczyć po rodzicach biologicznych na równi z dziećmi nieoddanymi do adopcji. ${ }^{61}$

Do sporządzenia testamentu uprawniona była każda pełnoletnia osoba, która w chwili sporządzania testamentu była poczytalna. Drugi warunek był spełniony nawet wtedy, kiedy testator, pomimo choroby psychicznej, w chwili sporządzania

58 Wyjaśnienie do § 2027, Privatrechtliches Gesetzbuch für den Kanton Zürich. Mit den Erläuterungen von Dr. Bluntschli Redaktor des Gesetzes, IV Band Erbrecht, Zürich 1856, s. 118.

$59 \S 2027$ PGB: „Ostatnia wola spadkodawcy jest prawnie skuteczna, o ile nie zostanie pominięte prawo rodziny do należnej obowiązkowej części spadku” (tłum.aut.).

${ }^{60} \S 2028$ PGB; kwota procentowego udziału w spadku była ustalana po odliczeniu długów.

${ }^{61} \S 2029$ PGB. 
testamentu znajdował się w stanie tzw. lucida intervalla, a zatem w stanie chwilowej poczytalności. ${ }^{62}$

Kodeks przewidywał dwie formy testamentu zwykłego i dwie formy testamentu nadzwyczajnego. Podstawową formą testamentu był testament zwykły własnoręczny. Dla jego ważności wymagano, aby testator osobiście sporządził go na piśmie, datował i podpisał, a następnie oddał notariuszowi na przechowanie. ${ }^{63}$ Notariusz w chwili otrzymania testamentu zobowiązany był do urzędowego zapieczętowania otrzymanego testamentu bez prawa wglądu w jego treść, a następnie do spisania protokołu zawierającego podstawowe dane osobowe testatora. ${ }^{64}$

Drugą formą testamentu zwykłego był testament publiczny. Było to oświadczenie woli złożone na wypadek śmierci w obecności notariusza i przynajmniej dwóch świadków ${ }^{65}$. Bezpośrednio po wyrażeniu woli przez spadkodawcę, notariusz spisywał treść testamentu w obecności wszystkich świadków, a następnie odczytywał ją testatorowi i świadkom, którzy po potwierdzeniu treści testamentu, podpisywali go wraz z notariuszem. ${ }^{66}$

Sporządzenie testamentu nadzwyczajnego dopuszczalne było w zasadzie w dwóch przypadkach: w razie groźby nagłej utraty życia lub w razie wybuchu epidemii. Były to testamenty ustne, z których pierwszy dla swej ważności wymagał złożenia oświadczenia w obecności trzech świadków i nastąpienia w terminie czterech dni od daty jego sporządzenia zgonu testatora lub utrwalenia się stanu wyłączającego sporządzenie przez niego testamentu zwykłego. W terminie czterech dni od oświadczenia złożonego przez testatora jeden ze świadków musiał zgłosić się do notariusza i zreferować mu treść testamentu, którą ten następnie spisywał w obecności wszystkich świadków ${ }^{67}$.

Oprócz testamentów PGB regulowało umowy o spadek (Erbvertrag). Najczęściej spotykaną formą umowy o spadek była wzajemna umowa małżonków. Wymagała ona formy testamentu zwykłego, podczas gdy wszystkie inne umowy o spadek wymagały formy aktu notarialnego. ${ }^{68}$ Taka wzajemna umowa o spadek zawarta pomiędzy małżonkami obejmowała z reguły prawo użytkowania określonych części masy spadkowej. Przepisy dotyczące umowy o spadek nie niweczyły przepisów dotyczących udziału obowiązkowego spadkobierców, ale w ograni-

${ }^{62}$ Wyjaśnienie do $§ 2054$, Privatrechtliches Gesetzbuch für den Kanton Zürich. Mit den Erläuterungen von Dr. Bluntschli Redaktor des Gesetzes, IV Band Erbrecht, Zürich 1856, s. 138.

$63 \S 2057$ PGB.

${ }^{64} \S 2058$ PGB.

${ }^{65}$ Zgodnie z $\$ 2060$ PGB świadkami nie mogły być osoby nieletnie, kobiety, osoby ślepe, głuche, dorosłe, ale pozostające pod opieką, analfabeci czy też zgodnie z § 2061 PGB osoby pozostające w bliskich relacjach z testatorem.

${ }^{66} \S 2059$ PGB.

$67 \S 2068$ PGB.

$68 \S 2116$ PGB. 
czonym stopniu je modyfikowały. $\mathrm{Z}$ reguły polegało to na przesunięciu w czasie objęcia posiadania odziedziczonych przedmiotów z uwagi na ustanowione przez spadkodawcę prawo użytkowania.

Umowa o spadek miała skutek prawnospadkowy, gdzie jedna strona umowy - spadkodawca w wiążący sposób zabezpieczała prawo do spadku albo druga strona umowy, czyli kontrahent spadkodawcy - potencjalny spadkobierca zrzekał się przysługującego mu w przyszłości prawa do spadku. ${ }^{69}$ Tym różniła się umowa o spadek od pozostałych umów wiążących, że w wyniku jej zawarcia nie powstawało roszczenie lub dług, ale otrzymywało się lub zrzekało się prawa do spadku. ${ }^{70}$ W tzw. pozytywnych umowach o spadek spadkodawca wyznaczał osobę spoza kręgu spadkobierców jako powołaną do spadku lub przyznawał spadkobiercy na określony czas szersze prawa do spadku niż byłoby to możliwe na podstawie pozostałych przepisów prawa spadkowego. W negatywnych umowach spadkobierca ustawowy zrzekał się prawa do części lub całości spadku po danym spadkodawcy.

Ocena całości rozwiązań PGB skupia się na podkreślaniu ludowego charakteru kodeksu (volkstümlich) i jego rdzennie germańskich korzeni. W tych cechach upatruje się także sukcesu jego przyjęcia i stosowania. Sam Bluntschli podkreślał, że ustawa ma szanse powodzenia, jeśli uda się pojąć istotę ducha prawa, który, nawet ukryty i nieuświadomiony, kieruje ludzkimi dążeniami. Ustawa ma szansę, jeśli uda się odczytać ludzką duszę i odkryć z niej potrzeby i prawa jednostki, jeśli uda się to wypowiedzieć zrozumiale dla ludu i uzyskać jego przychylność. ${ }^{71}$

Zdaje się być uzasadnioną teza, że PGB spełnia wymienione wyżej przesłanki. W kodeksie tym udało się połączyć politykę konserwatyzmu z wymogami współczesności, przemycając do jego treści, obok tradycyjnych germańskich rozwiązań, nowatorsko urządzone instytucje prawa prywatnego. Okoliczności polityczne związane z kompleksową reformą państwa przesądziły jednak o dość krótkiej, w porównaniu z innymi kodyfikacjami wieku oświecenia, popularności tej kodyfikacji. Początkowo postępujące zjednoczenie prawne ${ }^{72}$ wszystkich Kantonów Szwajcarii wymusiło przeprowadzenie, począwszy od lat siedemdziesiątych XIX wieku, kompleksowej rewizji kodeksu. ${ }^{73}$

W grupie zrewidowanych norm znalazły się przepisy dotyczące prawa spadkowego. Pierwszy projekt nowelizacji ustawy zakładający ograniczenie przywilejów dziedziczenia dla synów, zrównanie praw synów i córek w zakresie dziedzi-

$69 \S 2120$ PGB.

70 Wyjaśnienie do § 2120, Privatrechtliches Gesetzbuch für den Kanton Zürich. Mit den Erläuterungen von Dr. Bluntschli Redaktor des Gesetzes, IV Band Erbrecht, Zürich 1856, s. 177.

71 Za: A. Bauhoffer, op. cit., s. 60-61.

72 Chodziło przede wszystkim o wejście w życie Prawa Zobowiązań (OR) z 1881 roku, które pozbawiło mocy obowiązującej znaczą część PGB.

73 E. Huber, System und Geschichte..., s. 195. 
czenia majątku po ojcu, zrównanie praw dziedziczenia obojga małżonków i poszerzenie swobody testowania został odrzucony w referendum z dnia 30 czerwca 1878 roku, przede wszystkim ze względu na opór społeczny wobec zrównywania praw synów i córek do podziału masy spadkowej po ojcu. ${ }^{74}$ Jednakże już przy drugim podejściu w $1887 \mathrm{r}$. wszystkie te zmiany zostały przegłosowane i przyjęte. W tej zrewidowanej postaci PGB obowiązywało do wejścia w życie Szwajcarskiego Kodeksu Cywilnego, tj. do dnia 1 stycznia 1912 roku, kiedy to mocą przepisów wprowadzających uchylono wcześniejsze kantonalne ustawodawstwo cywilne (chyba że ZGB bezpośrednio się do niego odwoływało). ${ }^{75}$

\section{PRAWO SPADKOWE W KODEKSIE CYWILNYM SZWAJCARSKIM} (ZGB)

Porównując Szwajcarski kodeks cywilny z PGB w pierwszej kolejności uwidoczniają się różnice, przede wszystkim w poziomie redakcji językowej i precyzji systemowej obu kodeksów. Jest to wynik założonych przez twórcę ZGB Eugena Hubera celów stworzenia ustawy powszechnie zrozumiałej, co miało być osiągnięte dzięki użyciu możliwie prostych, jasnych i pozbawionych zbędnych ubarwień pojęć językowych, dzięki nieskomplikowanej budowie norm prawnych ujętych w krótkie paragrafy o zrównoważonym poziomie abstrakcyjności użytych w nich pojęć, które z jednej strony miały realizować postulat zupełności regulacyjnej, a $\mathrm{z}$ drugiej strony miały przeciwdziałać zbyt daleko posuniętej dowolności podejmowanych działań. ZGB miało być dalekie od widocznej jeszcze w PGB, kazuistyki i wolne od konieczności stosowania skomplikowanych odwołań systemowych w ramach samego kodeksu. ${ }^{76}$ Pomimo oczywistych różnic w przyjętej metodologii opracowania materiału normatywnego, treść i założenia ideologiczne obu ustaw pozostają spójne, a w wielu miejscach tożsame.

\section{DZIEDZICZENIE USTAWOWE}

Wyższy poziom opracowania naukowego jest szczególnie widoczny na przykładzie przepisów dotyczących dziedziczenia ustawowego, które w ZGB zamknięto w jedenastu artykułach, podczas gdy PGB poświęciło temu działowi aż

${ }^{74}$ A. Bauhoffer, op. cit., przypis 85, s. 27.

${ }^{75}$ Art. 51 przepisów wprowadzających i przejściowych Szwajcarskiego Kodeksu Cywilnego z 10 grudnia 1907 r. (The Swiss Civil Code, Concluding Title, Introductory and Inaugurating Provisions, Second Section- Inaugurating and Transferring Provisions, A. Repeal of the Cantonal Civil Law).

${ }^{76}$ E. Huber, Schweizerisches Zivilgesetzbuch ..., Einleitung, s.16-26 (s. 14-25 Erläuterungen). 
133 artykuły $^{77}$. Niemniej jednak treść niesiona przez obie ustawy jest silnie zbliżona. W ślad za przepisami kodeksu zuryskiego, ale także pozostałych kodeksów kantonalnych, w ZGB pierwszą grupę dziedziczenia (parentelę) stanowili zstępni spadkodawcy. W kodeksie cywilnym szwajcarskim była już przy tym mowa wyłącznie o dzieciach, które dziedziczą w częściach równych ${ }^{78}$ a nie, jak miało to miejsce w PGB, o zróżnicowanym prawie synów i córek do spadku (za wyjątkiem prawa dziedziczenia nieruchomości rolnych). Huber argumentował, że za uproszczeniem systemu dziedziczenia przemawiały przede wszystkim przesłanki natury ekonomicznej, ponieważ niekorzystne gospodarczo jest doprowadzanie w drodze dziedziczenia do nadmiernego rozdrobnienia majątku na skromne udziały procentowe (głównie w przypadku córek) poszczególnych dziedziców. Po drugie o zrównaniu praw córek i synów przemawiały zmienione stosunki społeczne zmierzające w kierunku zwiększenia udziału kobiet w życiu ekonomicznym. ${ }^{79}$

Drugą grupę dziedziczenia stanowili rodzice spadkodawcy. Pierwsze zdanie $\S 458$ ZGB jest dokładnym powtórzeniem $\S 1917$ PGB stanowiącym, że w przypadku, gdy spadkodawca nie pozostawi po sobie żyjących zstępnych, wówczas jego majątek dziedziczą rodzice. W dalszej części dyspozycji zaznaczają się już różnice wynikające ze zmienionych stosunków społecznych i rodzinnych, a dokładnie z postępującego równouprawnienia kobiet i mężczyzn. Mocą ZGB rodzice dziedziczyli w częściach równych. Kodeks nie przewidywał już żadnych szczególnych przywilejów ojca lub matki w odniesieniu do określonych składników majątku, odpowiednio po synu lub córce.

Ostatnią parentelę stanowili dziadkowie, którzy dziedziczyli w przypadku braku zstępnych i bliższych wstępnych. ${ }^{80}$ Choć prawo dziedziczenia gasło na poziomie dziadków spadkodawcy ${ }^{81}$, to w przypadku, w którym spadkodawca pozostawiłby wyłącznie żyjących pradziadków, ci mieliby prawo dożywotniego użytkowania majątku spadkodawcy w zakresie, jaki przypadałby zmarłemu spadkobiercy (dziecku pradziadków). Podobnie jak wobec pradziadków kształtowała się sytuacja rodzeństwa dziadków, jeśli pradziadkowie nie dożyliby prawa skorzystania z prawa użytkowania. ${ }^{82}$

Prawo spadkowe dzieci adopcyjnych zostało, co do zasady, uregulowane wzorem rozwiązań PGB, w szczególności jego § 1915, z tym zastrzeżeniem, że udział dzieci adoptowanych w przypadku, w którym dziedziczyły majątek rodzi-

$77 \S \S 1893-2026$.

$78 \S 457$ ZGB.

79 E. Huber, Schweizerisches Zivilgesetzbuch..., Das Erbrecht, s. 304-309 (s. 320-326 Erläuterungen).

$80 \S 459$ ZGB.

${ }^{81}$ W PGB ostatnią parentelę stanowili pradziadkowie (§ 1938 PGB).

$82 \S 460 \mathrm{ZGB}$. 
ców biologicznych wraz z ich pozostałymi dziećmi (nieoddanymi do adopcji) nie był pomniejszany o połowę w stosunku do udziału spadkowego rodzeństwa. Kodeks cywilny szwajcarski przewidywał za to ograniczenia wobec rodziców adopcyjnych. Kodeks prawa prywatnego Zurychu stanowił, że w przypadku gdy dzieci adoptowane nie pozostawią po sobie zstępnych, wówczas ich majątek przypadał po połowie rodzicom biologicznym i adopcyjnym (§ 1927 PGB). Regulacja kodeksu szwajcarskiego opierała się za to na zasadzie ograniczoności i jednostronności. Zasada ograniczoności polegała na tym, że prawo dziedziczenia dzieci adoptowanych obejmowało wyłącznie prawo do spadku rodziców adopcyjnych, ale już nie dalszych krewnych rodziców (np. dziadków). Zasada jednostronności stanowiła z kolei, że w przypadku adopcji jedynie dziecko zyskuje prawo do spadku po przysposabiających, ci zaś nie dziedziczyli majątku po przysposobionym. Prawo do spadku po dziecku było przywilejem rodziców biologicznych. ${ }^{83}$ Według Hubera za przyjęciem takiego rozwiązania przemawiały względy społeczne. Ustawa wskazywała wprawdzie na swobodę kształtowania stosunków prawnych, jednak jedynie na tyle, na ile nie stało to w sprzeczności z potrzebą ochrony wyższych wartości, do których zaliczano także ochronę wartości rodzinnych. Uznanie prawa dziedziczenia przez rodziców adopcyjnych po przysposobionym dziecku miało sprzyjać spekulacjom finansowym, wypaczających główną ideę przysposobienia, jaką było nawiązanie relacji osobistych, a nie majątkowych, pomiędzy przysposabiającym i przysposabianym. ${ }^{84}$

Całkowicie od nowa urządzono w ZGB kwestie spadkobrania małżonków. Pierwszą i najważniejszą zmianą, w stosunku do PGB, było zrównanie praw męża i żony w prawie do spadku po zmarłym współmałżonku. Po drugie, w realizacji wiodącej zasady ZGB - wolności kształtowania stosunków cywilnych, prawo to zostało znacznie rozszerzone w stosunku do wcześniej obowiązujących regulacji. Jeśli spadkodawca pozostawił po sobie dzieci, wówczas małżonek dziedziczył wedle własnego wyboru 1/4 majątku lub zyskiwał połowę majątku w użytkowanie. Jeśli dziedziczenie następowało w konkurencji z drugą parentelą, wówczas małżonkowi przypadała 1/4 majątku na własność i 3/4 majątku w użytkowanie. Jeśli spadkodawca pozostawił po sobie dziadków, wówczas małżonek otrzymywał $1 / 2$ majątku na własność i $1 / 2$ w użytkowanie. Dopiero jeśli małżonek był jedynym spadkobiercą wówczas przypadał mu na własność cały majątek po zmarłym współmałżonku. ${ }^{85}$

\footnotetext{
${ }^{83}$ P. Tuor, Das Schweizerische Zivilgesetzbuch..., s. 296.

${ }^{84}$ E. Huber, Schweizerisches Zivilgesetzbuch..., Das Erbrecht, s.309-311 (s.326-328 Erläuterungen).

$85 \S 462 \mathrm{ZGB}$.
} 
Podkreślenia wymaga fakt, że powyższe unormowanie stanowiło w kulturze szwajcarskiej zmianę wręcz zasadniczą. Do czasu uchwalenia ZGB wszystkie Kantony Szwajcarii hołdowały zasadzie ochrony więzów krwi. W niektórych Kantonach w ogóle nie istniało prawo do spadku po współmałżonku, a jedynie roszczenie do ograniczonego użytkowania części dawnego majątku wspólnego. ${ }^{86}$ Przyznanie w kodeksie cywilnym szwajcarskim prawa wdowy i wdowca do spadku po zmarłym współmałżonku wykreowało nową definicję rodziny. Więzy małżeńskie były od tej pory nie mniej istotne od więzów krwi i podlegały równej ochronie.

\section{DZIEDZICZENIE TESTAMENTOWE I UMOWY DZIEDZICZENIA}

Podobnie jak w PGB, ZGB przewidywało dwa podstawowe typy rozporządzeń mortis causa: testament i umowy dziedziczenia. Ich regulacja w ZGB wykazuje doskonalszą systematykę niż miało to miejsce w kodeksie zuryskim. Redaktor kodeksu cywilnego szwajcarskiego docenił rolę przepisów ogólnych będących zbiorem fundamentalnych zasad leżących u podstaw dalszych, bardziej szczegółowych norm. Czternasty tytuł ZGB poświęcony rozporządzeniom na wypadek śmierci otwierają przepisy dotyczące zdolności rozporządzania ( $\S 467-469$ ), następnie uregulowano kwestie wolności rozporządzania ( $\S 470-480)$ i sposobu dokonania rozporządzeń (§§ 481-497), aby dopiero w części czwartej szczegółowo opisać rozporządzenia dokonywane w formie testamentów.

Głębsza analiza przepisów skłania ku sformułowaniu twierdzenia, że redagując w ZGB przepisy dotyczące dziedziczenia testamentowego, ustawodawca dokonał roszady przepisów zuryskiego PGB jednocześnie usuwając zbędną kazuistykę i dostosowując je do zmienionych stosunków rodzinnych i społecznych. Co do zasady normy prawne obu kodeksów pozostają tożsame.

Mocą § 467 ZGB każda osoba zdolna do samodzielnego wyrażenia woli, która miała osiemnaście lat mogła dokonać rozporządzenia swoim majątkiem na wypadek śmierci, z zastrzeżeniem prawnych wymogów i ograniczeń. Treściowym odpowiednikiem tego przepisu w PGB jest $\S 2054$. Podobnie kształtuje się stosunek § 2027 PGB w zw. z § 2036 PGB i § 470 ZGB, regulujących zakres swobody testowania, $\mathrm{z}$ tą różnicą, że w ZGB pełna wolność testowania następowała w przypadku, w którym testator nie pozostawił po sobie żyjących zstępnych, małżonka, rodziców i rodzeństwa, a w kodeksie zuryskim następowała, jeśli testator nie pozostawił po sobie dziedziców ustawowych w dalszej linii pokrewieństwa aniżeli drugi stopień pokrewieństwa w grupie dziedziczenia dziadków.

Kodeks cywilny szwajcarski, choć niewątpliwie czerpał inspiracje z kodeksu zuryskiego, hołdował zasadzie ochrony interesów spadkobierców ustawowych

\footnotetext{
${ }^{86}$ P. Tuor, Das Schweizerische Zivilgesetzbuch..., s. 292.
} 
w sposób, który nie przeczył zasadzie swobody testowania. Jak wstępnie dało się odczytać z treści § 470 ZGB, kodeks z 1907 roku przyznawał o wiele szerszą swobodę rozporządzania majątkiem $\mathrm{w}$ formie testamentu niż miało to miejsce w PGB. W przypadku, w którym testator pozostawiłby po sobie dzieci, miałyby one prawo do 1/4 udziału, jaki przypadałby im, jeśli nastąpiłoby dziedziczenie ustawowe. Jeśli testator pozostawiłby po sobie żyjących rodziców, każde z rodziców mogłoby się ubiegać o połowę udziału, jaki przypadałby im gdyby nastąpiło dziedziczenie ustawowe. W przypadku rodzeństwa udział ten wynosiłby odpowiednio 1/4 udziału ustawowego. ${ }^{87}$

Przy okazji obliczania udziału współmałżonka sprawa nieco się komplikowała. Przede wszystkim roszczenie współmałżonka było ograniczone do roszczenia o prawo własności majątku, a nie o prawo użytkowania. ${ }^{88}$ Wysokość jego udziału w spadku zależała od tego, czy był jedynym spadkobiercą ustawowym, czy też oprócz niego uprawnione do zachowku były inne osoby ${ }^{89}$. W pierwszym przypadku ochronie podlegało roszczenie o połowę udziału ustawowego, w drugim wypadku całe roszczenie.

Co do zasady ZGB przewidywało, podobnie jak PGB, możliwość ustanowienia $\mathrm{w}$ testamencie na rzecz współmałżonka dożywotniego prawa użytkowania majątku pozostałego po zmarłym. Różnice kryły się już w szczegółach unormowania. Kodeks prawa prywatnego Zurychu stanowił, że testator ma prawo ustanowienia prawa dożywotniego użytkowania całości pozostawionego majątku, w tym także prawa użytkowania udziału obowiązkowego (zachowku) pozostałych spadkobierców ustawowych z tym zastrzeżeniem, że w przypadku, w którym dziedzicami ustawowymi są zstępni testatora, pełne prawo użytkowania przysługiwało współmałżonkowi tak długo, jak długo uprawnieni zstępni testatora nie uzyskali pełnoletniości lub nie wstąpili w związek małżeński. W takim wypadku współmałżonek testatora miał prawo do użytkowania połowy pozostawionego przez spadkodawcę majątku. ${ }^{90}$

W ZGB prawo użytkowania obejmowało wyłącznie udział współmałżonka i wspólnych dzieci. Uzasadnieniem takiego uregulowania był fakt, że pozostały przy życiu współmałżonek był niejednokrotnie w podobnym wieku co dzieci testatora z poprzedniego małżeństwa, a przyznanie praw użytkowania pozostającemu przy życiu obecnemu współmałżonkowi mogłoby realnie pozbawić tych zstępnych możliwości cieszenia się częścią majątku po zmarłym rodzicu. ${ }^{91}$

$87 \S 471 \mathrm{ZGB}$.

88 P.Tuor, Das Schweizerische Zivilgesetzbuch..., s. 309.

${ }^{89}$ Ustawa nie używa tego terminu, posługuję się nim wyłącznie dla zachowania jasności wywodu.

90 \& 2039 PGB.

91 P Tuor, Das Schweizerische Zivilgesetzbuch..., s. 310. 
Ustanowione $\mathrm{w}$ testamencie prawo użytkowania zastępowało prawo do odziedziczenia części majątku na własność. Z chwilą, w której pozostający przy życiu współmałżonek wstąpił w kolejny związek małżeński, jego zakres był ograniczany do połowy majątku. ${ }^{92}$

Rozporządzenia na wypadek śmierci można było dokonać w formie testamentu lub w formie umowy o spadek..$^{93}$ Umowy spadkowe były instytucją znaną już w kodeksie zuryskim, a ślady jej oddziaływania na kształt regulacji w ZGB są nadal widoczne. Przede wszystkim nie zmienił się zakres treściowy tych umów. Podobnie jak w § 2120 PGB, kodeks szwajcarski stanowił, że spadkodawca mógł zawrzeć $\mathrm{z}$ dziedzicem umowę o przyjęcie lub o zrzeczenie się prawa do spadku. ${ }^{94}$ Regulacja kodeksu szwajcarskiego w dalszej części regulacji szczegółowych tym różniła się od przepisów kodeksu prawa prywatnego Zurychu, że operowała ujednoliconymi zasadami zawierania i rozwiązywania tych umów, podczas gdy w kodeksie zuryskim przeważało ujęcie kazuistyczne.

Za przykład mogą posłużyć przepisy dotyczące formy zawierania umów o spadek. ZGB przewidywało wyłącznie formę właściwą dla testamentu publicznego, tj. formę aktu notarialnego ( $\$ 512$ ZGB). W PGB wzajemna umowa o spadek między małżonkami mogła być zawarta w zwykłej formie pisemnej (§ 2116 PGB), zaś wszystkie pozostałe umowy wymagały formy testamentu publicznego (spisane i opieczętowane przez notariusza), choć dla jego ważności nie wymagano obecności dwóch świadków (§ 2119 PGB).

Podobnie kształtowała się sytuacja w przypadku rozwiązania umów spadkowych. Mocą § 513 ZGB umowa o spadek mogła być w każdej chwili rozwiązana późniejszą pisemną umową obu stron kontraktujących. Istniała także możliwość jednostronnego rozwiązania umowy, jeśli po zawarciu umowy kontrahent zachowywałby się wobec spadkodawcy w sposób, który stanowiłby podstawę do wydziedziczenia. ${ }^{95}$

$92 \S 473$ ZGB.

${ }^{93} \S 481 \mathrm{ZGB}$.

${ }^{94} \S 495 \mathrm{ZGB}$.

${ }^{95}$ Zarówno kodeks cywilny szwajcarski, jak i kodeks Zurychu regulowały instytucję wydziedziczenia, tj. pozbawienia dziedziców ustawowych prawa do zachowku. Mocą § 477 ZGB testator mógł pozbawić dziedzica obowiązkowego udziału w spadku jeśli ten dopuścił się względem testatora ciężkiego przestępstwa lub zaniechania obowiązków rodzinnych, które doprowadziły do naruszenia bliskich związków rodzinnych. Za: P Tuor, Das Schweizerische Zivilgesetzbuch..., s. 317. Wydziedziczenie miało ten skutek, że wydziedziczonego traktowało się tak, jakby nie dożył otwarcia spadku (§ 478 ZGB). Podobne rozwiązanie przewidywał PGB, jednakże katalog czynów mogących być podstawą wydziedziczenia był szerszy i obejmował, oprócz czynów opisanych w ZGB, także popełnienie jakiegokolwiek przestępstwa, które świadczyłoby o braku moralności dziedzica czy prowadzeniu rozwiązłego trybu życia (§ 2042 PGB). 
Przepisy ZGB znowu co do zasady pozostawały spójne z przepisami wcześniej obowiązującego PGB, jednak te ostatnie były zdecydowanie bardziej rozbudowane i miały charakter kazuistyczny. Mowa tu w szczególności o rozwiązaniu ex lege umowy spadkowej zawartej pomiędzy małżonkami z chwilą ich rozwodu. Drugim przykładem ustawowego „rozdrobnienia” może być prawo jednostronnego rozwiązania umowy spadkowej, na mocy której tylko dziedzic był beneficjentem umowy, z powodu okazanego dziedzicowi braku wdzięczności lub z powodu urodzenia się dziecka spadkodawcy, który w chwili zawierania umowy był bezdzietny. ${ }^{96}$ Punktem wyjściowym dla przepisów szczegółowych była przy tym norma $\S 2134$ PGB stanowiąca, że wzajemną umowę o spadek można rozwiązać w sposób przewidziany dla odwołania testamentu, zaś wszystkie pozostałe umowy spadkowe poprzez dokonanie notarialnego skreślenia (§ 2137 PGB).

\section{PODSUMOWANIE}

Określenie Kodeksu Prawa Prywatnego Kantonu Zurychu mianem „najdoskonalszego wzorca" dla Kodeksu Cywilnego Szwajcarskiego jest trafne, choć w mojej opinii przesadzone i wymagające rozwinięcia. Podstawowy związek pomiędzy PGB i ZGB wyraża się w metodzie prowadzenia prac przygotowawczych do prac kodyfikacyjnych, jak i w przyjętym sposobie doboru materiału źródłowego mającego służyć za materiał poglądowy w pracach unifikacyjnych. U jego źródeł leży nauka szkoły historycznej prawa w jej germańskim odłamie, której zwolennikami był zarówno Johann Caspar Bluntschli, jak i Eugen Huber. ${ }^{97}$ Zgodnie z nauką szkoły historycznej, każdy naród ma swój indywidualny charakter, swojego ducha (Volksgeist), który pozostawia ślad na wszystkich ludzkich instytucjach, w tym na prawie. Właściwe przeprowadzenie prac kodyfikacyjnych jest osiągalne dopiero wtedy, kiedy w pełni zrozumie się przedmiotowe materie, a będzie to możliwe dopiero po gruntownym zbadaniu i przeniknięciu wszystkich praw obowiązujących na obszarze przyszłej kodyfikacji. ${ }^{98}$ Twierdzenia te opierały się na założeniu, że przy bliższej analizie niektóre dawne instytucje prawne, wyrosłe na kanwie narodowej tradycji, są ,naturalnymi” instytucjami danego naro-

\footnotetext{
$96 \S 2136$ PGB.

${ }^{97}$ Za twórcę szkoły historycznej uważa się Friedricha Karla von Savigniego, który w odpowiedzi na esej Antona Thibauta O konieczności ogólnego kodeksu cywilnego dla Niemiec (A.F.J. Thibaut, Über die Notwendigkeit eines Allgemeinen Bürgerlichen Rechts in Deutschland, Heidelberg 1814) opublikował dzieło zatytułowane $O$ powołaniu naszych czasów do ustawodawstwa i nauki prawa (z jęz. niemieckiego przełożył i wstępem opatrzył K. Opałek, Warszawa 1964).

98 J. M. Kelly, Historia zachodniej teorii prawa, Kraków 2006, s. 348-349.
} 
du, inne zaś mogą okazać się „nienaturalne”, jako że są błędnymi przeszczepami, pochodzącymi z obcego inwentarza. Tych ostatnich nie należy utrwalać w sztywnej formie kodeksu. ${ }^{99}$ Idea ta niewątpliwie przyświecała tak Buntschliemu, jak i Huberowi, który podkreślał, że „das Gesetz muss aus den Gedanken des Volkes heraus gesprochen sein" 100 .

Germaniści ${ }^{101}$, jak Bluntschli i Huber, dążyli do wskrzeszenia prawa rdzennie niemieckiego i wszechstronnego jego opracowania w doktrynie. Głosili hasła stworzenia jednolitego prawa niemieckiego na gruncie tradycji germańskich, obrony "ducha narodowego" i świadomości narodowej. ${ }^{102}$ PGB miało stanowić wierną realizację założeń szkoły historycznej. Przystępując do prac nad kodeksem dla Kantonu Zurychu, Bluntschli ${ }^{103}$ ostrożnie dokonywał selekcji opracowywanego materiału, pozostawiając na koniec kodyfikację prawa spadkowego jako działu prawa silnie ingerującego w prywatną sferę życia. Zabieg ten, choć może nieuświadomiony, pozostawał w zgodzie z nauką Savigniego o stosunku nieprawników do kodeksu. Savigny pisał, że „pewne materie interesują żywo i bezpośrednio nieprawnika, inne jako obojętne pozostawia się samej technice prawniczej: do pierwszej kategorii należy w większym stopniu prawo rodzinne, do drugiej części prawo majątkowe (...). To, co zostanie o nich [instytucjach - przyp. ML], stosuje się zarazem do całej klasy zagadnień, do których one należą." 104 Do klasy zagadnień prawa rodzinnego należy zaliczyć w tym wypadku także prawo spadkowe, gdyż pozostaje ono w gronie osobistego zainteresowania nieprawników. Szczególnie ten dział prawa wymagał pojęcia owego „ducha narodu”, który nawet ukryty i nieuświadomiony kieruje ludzkimi poczynaniami. Bluntschli trafnie rozpoznał rdzeń tradycji spadkobrania na terytorium Kantonu Zurychu, następnie ustalił prawidłowy stosunek tradycji do wymogów współczesności, by ostatecznie przekuć wnioski z przeprowadzonych analiz na język ustawy.

Tę samą metodę pracy nad kodeksem ogólnoszwajcarskim przyjął Eugen Huber. ${ }^{105}$ Jeszcze przed przystąpieniem do pracy Huber podkreślał, że zadaniem usta-

99 Ibidem, s. 349.

100 E. Huber, Schweizerisches Zivilgesetzbuch..., s. 6 (s.2 Erläuterungen).

101 Termin „germaniści” oznaczający pewien kierunek w nauce prawa powinien być rozumiany szerzej niż przynależność do szkoły historycznej. Do germanistów należeli nie tylko ci, którzy należeli do szkoły historycznej, ale wszyscy, którzy podejmowali działania w imię odrodzenia prawa rdzennie niemieckiego. Za K. Sójka- Zielińska, W sprawie oceny ..., s. 139.

102 Ibidem, s. 132-133.

103 Bluntschli był doskonałym wyborem, jeśli chodzi o przygotowanie kodyfikacji prawa cywilnego dla Kantonu Zurychu. Nie tylko miał doświadczenie w praktykowaniu prawa, lecz także był znawcą historii i dziejów prawa Zurychu, czego dał wyraz w opublikowanym w 1838 r. dziele Staats und Rechtsgeschichte der Staat und Landschaft Zürich.

104 F.C. von Savigny, op.cit., s. 81-82.

105 P. Liver, Huber Eugen [w:] Neue Deutsche Biographie 9 (1972), wydanie internetowe: http:// www.deutsche-biographie.de/pnd118554026.html, s. 690-692. 
wodawcy państwa z tak bogatą historią jak Szwajcaria jest ochrona wyjątkowości i oryginalności prawa. Kantony z trudem zachowują swoje tradycje nie mogąc skutecznie bronić się przed wpływami z zewnątrz. Zadaniem ustawodawcy Konfederacji jest zachowanie praw Kantonów, to jest wyłuskanie wspólnego typu norm przy wykluczeniu niektórych zbędnych różnic". ${ }^{106}$ Redagując prawo spadkowe Huber odwoływał się, podobnie jak Bluntschli, do tradycji i norm wcześniej obowiązujących. W wyjaśnieniu do ustawy Huber przedstawił szerokie spektrum analityczne, ostatecznie zwracając się ku rodzimym rozwiązaniom, którego nośnikiem nie był jednak sam PGB. Tytułem przykładu, Huber opierając się na badaniach porównawczych wszystkich obowiązujących w Szwajcarii ustaw ${ }^{107}$ stwierdził, że zgodnie $z$ tradycją zasadą jest dziedziczenie ustawowe, a swoboda testowania uznawana jest tylko wtedy, gdy zezwalają na to obowiązki wobec rodziny i ogółu. ${ }^{108} \mathrm{~W}$ pracach nad PGB Bluntschli również uznawał tę zasadę jako wiodącą i dlatego opracował testamenty pobieżnie i mało precyzyjnie, skupiając się na dziedziczeniu ustawowym, podczas gdy Huber realizując postulat przystosowania ustawy do wymogów współczesności, a także zagwarantowania realizacji głównej idei ZGB, jaką była swoboda kształtowania stosunków cywilnych, szeroko i precyzyjnie uregulował kwestie dziedziczenia testamentowego. Rozbieżności uregulowań PGB i ZGB dotyczyły także obszarów dotyczących uprawnienia kobiet do spadkobrania, udziału rodziny żony w procesie dziedziczenia, dziedziczenia po dzieciach adopcyjnych, udziałów spadkowych, dziedziczenia małżonków itd. Brakuje zatem dowodów świadczących o tym, że ZGB w obszarze prawa spadkowego opierał się na uregulowaniach PGB i że w odniesieniu do treści ustawy to kodeks zuryski stanowił ów „,najdoskonalszy wzorzec". Bliskość związku obu ustaw wyraża się nie w treści, a w założeniach ideologicznych prowadzenia prac kodyfikacyjnych.

\section{THE ORIGIN AND SIGNIFICANCE OF THE CODE OF PRIVATE LAW IN THE CANTON OF ZURICH FOR THE CODIFICATION OF PRIVATE LAW IN SWITZERLAND ON THE EXAMPLE OF INHERITANCE LAW}

\section{Summary}

The Code of Private Law in the Canton of Zurich (Privatrechtliches Gesetzbuch für den Kanton Zürich - PGB) is described as the perfect model for the Swiss Civil Code in the literature devoted to the subject matter of codification of private law in the Swiss

106 E. Huber, System und Geschichte des schweizerischen Privatrechts, T. IV, Basel 1893, s. 207.

107 Zob. E. Huber, Schweizerisches Zivilgesetzbuch..., Das Erbrecht, s. 320 i (s. 338 Erläuterungen).

${ }^{108}$ E. Huber, Schweizerisches Zivilgesetzbuch: Erläuterungen zum Vorentwurf des Eidgenössischen Justiz- und Polizeidepartements, Bern 1914, s. 323 (s. 341-342 Erläuterungen). 
Confederation. It was the first modern civil code in Switzerland which was imbued with German tradition and legal culture. At the same time, it represented a high level of scientific sophistication. The Code of Private Law in the Canton of Zurich proved the vitality of German law in Switzerland. Moreover, its stable foundations in the national spirit resulted in a high level of social acceptance for the legal solutions included within. However, the question remains to what extent one can determine the influence of the Code of Private Law in the Canton of Zurich on the project and on the final shape of the Swiss Civil Code (ZGB). Also the question is to what extent one should treat these codes as independent works, even though they were created on the basis of the same initial assumptions. The influence of The Code of Private Law in the Canton of Zurich on the Swiss Civil Code most completely depicts the inheritance law. Firstly, it directly interferes with the personal sphere of a citizen's life and, consequently, it has to be rooted in the national culture and tradition in order to be effective. Secondly, it is the part of law which was the most diversified regulatory area in Switzerland in the period prior to the unification.

The description of the Code of Private Law in the Canton of Zurich as "the perfect model" for the Swiss Civil Code is accurate. However, it is the author's opinion that this statement is an exaggeration. The basic connection between the Code of Private Law in the Canton of Zurich and the Swiss Civil Code is expressed in the method of conducting the preparatory work for the codification work. It is also expressed by the adopted method of selection of the source material which was to serve as demonstrative material in the unification work. However, there is no evidence which would attest that the Swiss Civil Code's contents were based on the regulations found in the Code of Private Law in the Canton of Zurich. The close relationship of both laws is expressed not in the contents but rather in the ideological assumptions of the conducted codification works.

\section{LES ORIGINES ET L'IMPORTANCE DU CODE DE DROIT PRIVÉ DU CANTON DE ZURICH POUR LA CODIFICATION DU DROIT PRIVÉ EN SUISSE EN SE BASANT SUR L'EXEMPLE DE LA LOI SUR LA SUCCESSION}

\section{Résumé}

Dans la littérature sur la codification du droit privé de la Confédération suisse, le Code de droit privé du Canton de Zurich (Privatrechtliches Gesetzbuch für den Kanton Zürich $-P G B)$ est considéré comme le modèle le plus parfait du Code civil suisse. C'était le premier code civil moderne en Suisse, s'appuyant sur la tradition allemande et de sa culture juridique, qui se situait en même temps à un niveau élevé des recherches scientifiques. Le PGB a témoigné de la vitalité du droit allemand en Suisse et sa fixation stable dans l'esprit national traduite par un niveau élevé d'acceptation sociale de ses solutions juridiques.

Il se pose la question de savoir si le PGB influençait, et dans quelle mesure, la conception et la forme finale du Code civil suisse (ZGB) ou si ces codes sont censés être traités comme des œuvres indépendantes, bien que créés sur la base des mêmes hypothèses initiales. L'impact possible du PGB sur le ZGB est mieux illustré par le chapitre consacré à la loi de succession qui - premièrement - touche directement la sphère personnelle de la vie du citoyen, et par conséquent, pour être efficace, le code doit être intégrée dans la culture 
de la nation et sa tradition; deuxièmement - c'est un domaine du droit qui, dans la période précédant l'unification, était le champ de réglementation le plus diversifié en Suisse.

La reconnaissance du Code de droit privé du Canton de Zurich comme «modèle le plus parfait» du Code civil suisse est juste mais exagérée à mon avis. La relation essentielle entre le PGB et le ZGB est basée sur la méthode des travaux préparatoire pour l'œuvre de codification ainsi que sur la méthode utilisée pour la sélection de la matérielle source qui devait servir de matériau de référence dans les travaux d'unification. Cependant, il n'y a aucune preuve que le ZGB était basé sur la réglementation PGB en ce qui concerne le contenu du code. Le rapprochement de ces deux lois ne s'exprime pas dans leur contenu mais dans les hypothèses idéologiques de la conduite des travaux de la codification. 
